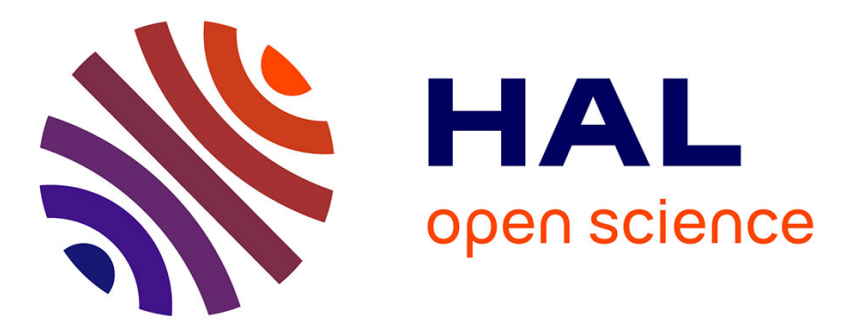

\title{
Participatory guarantee systems: alternative ways of defining, measuring, and assessing "sustainability"
}

Allison Marie Loconto, Maki Hatanaka

\section{To cite this version:}

Allison Marie Loconto, Maki Hatanaka. Participatory guarantee systems: alternative ways of defining, measuring, and assessing "sustainability". Sociologia Ruralis, 2017, Online (Online), pp.n/a-n/a. 10.1111/soru.12187 . hal-01581625

\section{HAL Id: hal-01581625 \\ https://hal.science/hal-01581625}

Submitted on 26 May 2020

HAL is a multi-disciplinary open access archive for the deposit and dissemination of scientific research documents, whether they are published or not. The documents may come from teaching and research institutions in France or abroad, or from public or private research centers.
L'archive ouverte pluridisciplinaire HAL, est destinée au dépôt et à la diffusion de documents scientifiques de niveau recherche, publiés ou non, émanant des établissements d'enseignement et de recherche français ou étrangers, des laboratoires publics ou privés.

\section{다(1)(2)}

Distributed under a Creative Commons Attribution - ShareAlikel 4.0 International 


\section{Participatory Guarantee Systems: Alternative Ways of Defining, Measuring, and Assessing "Sustainability"}

Dr. Allison Loconto (1)

Chargée de recherche

Institut National de la Recherche Agronomique (INRA)

Laboratoire Interdisciplinaire Sciences, Innovations et Sociétés (UMR LISIS)

University of Paris-Est Marne-la-Vallée (UPEM)

5 blvd Descartes

77420 Champs-sur-Marne France

Email: allison-marie.loconto@inra.fr

(corresponding author)

Dr. Maki Hatanaka

Associate Professor

Sam Houston State University

1905 University Ave

Huntsville, TX 77340, USA

Email:maki.hatanaka@shsu.edu

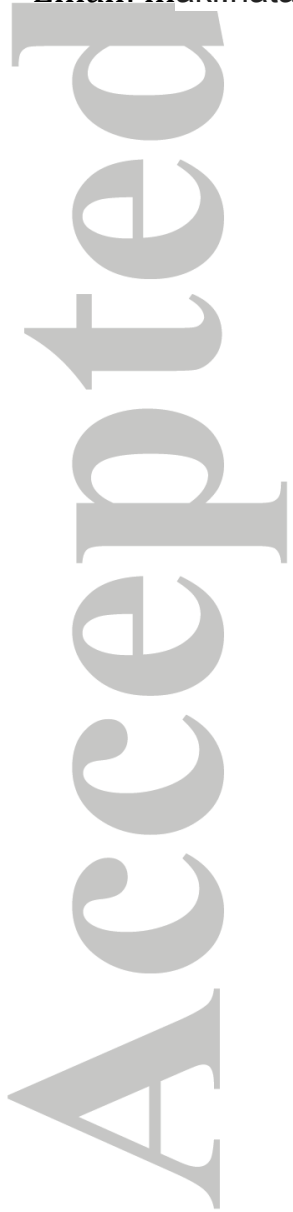

This article has been accepted for publication and undergone full peer review but has not been through the copyediting, typesetting, pagination and proofreading process which may lead to differences between this version and the Version of Record. Please cite this article as an 'Accepted Article', doi: 10.1111/soru.12187 


\section{Abstract}

Over the past twenty years, standards and certification have become the leading governance mechanism for determining what sustainability entails, how to measure it, and how to assess it. This system of sustainability standards has generally relied upon the third-party certification (TPC) model to ensure that producers are complying with standards. Over the past ten to fifteen years, critiques of this model have emerged in both practitioner and academic circles that question the appropriateness of this model based on the type of knowledge that is privileged, the marginalization of some actors, and the allocation of accountability to individual rather than collective actors. We draw upon case studies from Japan and Chile to examine the ways that participatory guarantee systems (PGS) institute practices for defining, measuring, and assessing sustainability that empower local actors - both producers and consumers. Our cases illustrate that expert and lay knowledges are both relevant and often have different strengths. We argue that PGS offer an alternative approach to sustainability governance, one that may be more democratic and hence, produce forms of sustainability that incorporate the lived experiences of people around the world.

\section{Introduction}

Sustainable agriculture is a core development concern for the 2030 horizon. This is apparent in the international events leading up to the publication of the Sustainable Development Goals in 2015. In September 2014, the Food and Agriculture Organization of the United Nations (FAO), with support from the French government, organised the largest ever scientific symposium on Agroecology. ${ }^{i}$ The purpose was to promote dialogue at the intergovernmental level about the role that agro-ecological techniques can play in achieving sustainable agri-food systems. In October 2014, the Committee on World Food Security approved the Principles for Responsible Investment in Agriculture and Food Systems, despite Oxfam's public statement that these principles are "too weak, vague and in a number of areas are actually worse than the standards that already exist. Unscrupulous investors could find ways to use the principles to cover irresponsible deals." ii In November 2014 the Second International Conference on Nutrition (ICN2) ${ }^{\text {iii }}$ was held twenty-two years after the first one. Here, governments (including the Pope), private sector and civil society representatives made commitments, captured in the Rome Declaration on Nutrition, to transform food systems towards providing more nutritious diets for all citizens. The parallel restructuring of the FAO around five strategic priorities includes 'making agriculture, forestry and fisheries more productive and sustainable'.iv

These international discourses reflect changes in public debates around agri-food systems that have begun to take into consideration the positions promoted by grassroots and international social movements. At the same time, the types of commitments and the terms of debate at these high-level discussions also reflect the fact that the politics of the sustainability of agri-food systems are deeply embedded in their technical discussions. For example, FAO's Director General José Graziano da Silva stated in his address to the UN Secretary General Climate Summit that: "Climate-smart agriculture and Agro-ecology as well as the Genetic Modified Organisms could be complementary options and need to be considered under a real scientific approach not in passionate ideological discussions." sustainable agriculture, who will be able to 'own' the land where it should take place, and who will have access to nutritious food (however it will be defined) - have not been resolved in these recent public debates, but are rather relegated to science and technology. What this often means 
is that an overtly political issue is turned into a technical issue that can only be resolved by 'experts', who offer competing and oftentimes equally political solutions that are very much embedded in their expert communities (Collins, 2014). As a result, sustainability remains a fuzzy concept with multiple definitions, blurred boundaries and numerous criteria and indicators (Levin et al., 2012).

In this article, we address how to define, measure, and assess sustainability by exploring experiments in one of the most widely promoted tools of sustainable agricultural development: standards and certification. Under contemporary neoliberalism, standards and certification have become the leading governance mechanism for determining what sustainability entails, how to measure it, and how to assess it (Milder et al., 2015; Fransen, 2015; Busch, 2011a). These standards use science-based methods (Bain et al., 2010) to determine compliance with specific sets of values developed by a range of international organisations, which make claims about the ability of these standards to influence the sustainability of practices (Reinecke, 2010). Sustainability standards (e.g., Forest Stewardship Council, Fairtrade) have long been hailed as success stories in both models of private or hybrid governance and in delivering development impacts (Marx, 2012). The governance model used by these standards follows a typical structure: independent standard-development organisations create sustainability standards and accredited third-party certifiers ensure suppliers' compliance with the standards (Loconto and Busch, 2010; Loconto, 2017; Fouilleux and Loconto, 2016). The legitimacy of this structure is an outcome of the embeddedness of standards and audits in the scientific norms of objectivity, replicability, and validity (Power, 1997; Porter, 1995; Lytton, 2014).

Nonetheless, both practitioners and academics critique third-party governance. First, as demonstrated by science and technology scholars, the type of knowledge that this model privileges (i.e., scientific and expert knowledge), is neither value-free nor neutral (Ransom et al., 2017; Bain et al., 2010; Busch, 2011b; Hatanaka, 2010a). The result, at least in some cases, has been the marginalisation of specific actors in sustainability governance (e.g., small-scale farmers, consumers) (Cheyns, 2011). Second, research has shown that the quantitative and uniform indicators (i.e., standards and audits) used in third-party governance are not able to capture the complexity of objects and practices on the ground (Raban, 2010: 177; Hatanaka, 2010b; Loconto, 2014; Loconto, 2015). Third, the practices of third-party governance are black-boxed to public scrutiny, thus raising questions of democratic accountability (Busch, 2011a; Ponte and Cheyns, 2013).

Building on these critiques, by using recent theories of valuation and standards, this paper explores the valuation processes used in alternative approaches to defining, measuring, and assessing sustainability. Participatory guarantee systems (PGS), which reallocate authority away from experts to a multi-stakeholder group, have become a viable certification alternative for organic standards. First used in the 1970s in France and Japan, PGS are now implemented or

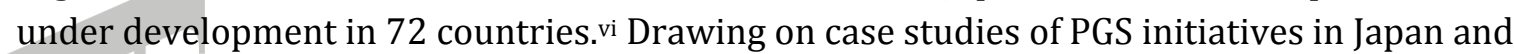
Chile, this paper examines the ways that PGS institute practices for defining, measuring, and assessing sustainability that empower local actors - both producers and consumers. Our cases illustrate that expert and experiential knowledges are both relevant and often have different strengths that are necessary for governing sustainability. Thus, governance approaches that build and foster relationships across governments, private actors, and civil society at multiple levels of action is necessary (cf. Denny et al., 2016). This paper will offer insightful inputs on "knowing sustainability", which has been largely taken for granted in third-party governance 
(i.e., relying on science and technical knowledge). Specifically, we argue that PGS offer an alternative approach to sustainability governance, one that may be more democratic in terms of the types of knowledge that it prioritises and hence, produces forms of sustainability that incorporate the lived experiences of people around the world.

\section{Knowing Sustainability}

We find ourselves in an epoch where it is nearly impossible to ignore the prioritisation of a specific form of knowledge: scientific knowledge. This type of expert knowledge has often been put into contrast with lay knowledge (Wynne, 1996), amateur knowledge (Meyer, 2010), indigenous or traditional knowledge (Agrawal, 2014), experiential knowledge (Collins, 2014) or marginalised knowledge (Harding, 1991) - but often with a disclaimer about the dangers of underestimating their importance and their hybridity. As Lord Kelvin famously explained: "when you can measure what you are speaking about, and express it in numbers, you know something about it; but when you cannot measure it, when you cannot express it in numbers, your knowledge is of a meagre and unsatisfactory kind: it may be the beginning of knowledge, but you have scarcely, in your thoughts, advanced to the stage of science" (Lide, 2001: 1). It is for this reason that defining, measuring, and assessing sustainability are fundamental to both knowing what this very concept is and ensuring that it is put into action. Put differently, defining, measuring and assessing are fundamental activities for knowing and acting in the world - and we must pay more attention to them.

We build our conceptual framework from the perspective that standards are 'recipes for reality' (Busch, 2011b) - that is, they are very specific ways to define, measure and assess people, products, and processes (Bingen, 2002). In this sense, standards work as socio-technical imaginaries (Jasanoff and Kim, 2009) that describe a set of collectively imagined forms of social life and social order that are reflected in the design and fulfilment of international scientific and/or technological projects. A socio-technical imaginary explains that these forward-looking visions are guided by a type of 'knowing in action' based on differences found in creative purposes and in epistemic spaces (Amin and Roberts, 2008). The standardisation of imaginaries, and the knowledge they prioritise, into material forms (in our case, into standards) enables that knowledge to circulate (Star, 1999), and in doing this, it also enables some actors to govern the actions of others, often in different geographic and epistemic spaces (Lascoumes and Le Gales, 2007).

Thus, the ability to define and measure is a politics-laden exercise. We see this clearly in the social studies of models and metrics (Bowker and Star, 1999; Dagiral et al., 2016; Freidberg, 2013; Boullier, 2016; Leach and Scoones, 2013a; 2013b), whereby specific political programmes are forwarded by the selection of variables or measurements or even what to measure. For example, Aubert et al. (2016) demonstrate how civil society actors were able to have their concerns listened to once they were able to propose a new metric that could more easily measure 'zero deforestation' through a redefinition of the forest via the terminology of high carbon stocks. Metrics and indicators (and particularly standards) are also performative (Muniesa et al., 2007; MacKenzie, 2007; Ouma, 2015; Busch, 2007; Loconto, 2010) and thus, they can have both intended and unintended changes on reality. For example, the focus of Life Cycle Assessment and climate models on quantifying $\mathrm{C} 02$ has slowly shifted the debates on Climate Change towards a near exclusive focus on how to mitigate C02 in lieu of adapting or alleviating the drivers of climate change such as land use, biodiversity or social organization of supply chains (Freidberg 2013, Freidberg 2014). Thus, a specific way of knowing can (un)wittingly 
affect the type of information that is used to measure another type of knowledge, which in turn changes what we know.

Assessing, too, can be a political exercise. There is significant power to be found in the interpretation of standards, which is a clear concern of the standard-setters who see this as a threat to the credibility of their definition of sustainability (Loconto and Barbier, 2014). For example, auditors can choose to accept or ignore some forms of evidence (Silva-Castañeda, 2012) or they can decide to adapt their procedures and practices to the local conditions (Hatanaka, 2010b). While there is an inherent conflict of interest in the third-party certification model (Lytton, 2014), the need to overcome this conflict by increasing the normative and prescriptive character of standards has further eroded the assessor's ability to evaluate sustainability as the audits have become tick-box exercises that prohibit auditors from taking context and qualitative practices into account (McDermott, 2012). Indeed, the formalisation, rationalisation and standardisation of control in the system eroded trust between producers, certifiers and standards-setters (Hatanaka, 2014).

These "knowledge politics" (Baert and Rubio, 2012) suggest that we should be asking ourselves important questions as we begin to measure sustainable agriculture specifically and sustainable development more generally. We need to be asking: what types of knowledge and whose knowledge (Harding 1991) is taken into consideration in some of the more commonly used indicators and analytical methods? Given the performative nature of some dominant forms of expertise (MacKenzie et al., 2007), what phenomena do these indicators actually measure? What are the implications of this type of measurement within the politics and practice of sustainability governance? To begin to address these questions, we examine two case studies of alternative certification mechanisms that define, measure, and assess sustainability very differently from the predominant third-party governance mechanism. We argue that it is important to consider alternative ways of "knowing sustainability" (i.e., PGS), because how we know the world also determines what we know of the world and also how we will make the world of the future.

\section{What are Participatory Guarantee Systems?}

Within the field of sustainability standards, participatory guarantee systems (PGS) have received increasing attention over the past ten years following a formalisation of the concept by the International Federation of Organic Agriculture Movements (IFOAM) in 2004. While the dominant models of assurance allocate oversight authority to third-party certifiers or standardssetters (Loconto, 2017), PGS focus on a democratisation of knowledge whereby the oversight systems for compliance with standards are created by producers, experts and consumers who collectively ensure that the organic agriculture techniques are adopted (IFOAM, 2008).

Typically, PGS are networks created within local communities and consist of farmers, experts, public sector officials, food service agents, and consumers (Radomsky et al., 2014; Poméon et al. 2017). "They certify producers based on active participation of stakeholders and are built on a foundation of trust, social networks and knowledge exchange."vii While individual PGS do not present themselves in direct opposition to state-led third-party certification, they do seek to anchor themselves in their local contexts by favouring citizen-led alternatives to sustainable food systems (Mundler and Bellon, 2011). The aim of this type of network is to create a local system of production and consumption whereby multiple stakeholders experiment with sustainable agriculture technologies on farms, but also collectively ensure that the organic agriculture techniques are adopted by setting standards and verifying their compliance (IFOAM, 
2008). In sum, PGS serve to provide a direct guarantee, through the formation of a local market, for sustainably produced food and agriculture products (Loconto and Vicovaro, 2016).

During its 2004 meeting in Porto Alegre Brazil, IFOAM took stock of how PGS (referred to at the time as Alternative Certification Schemes) in 17 countries across the Americas, Africa and Asia differed from other approaches to certification, specifically with regards to how they assured transparency, documentation and who conducted the controls:

"Although the Alternative Certification schemes (ACs)* represented at the workshop all have very different backgrounds and function in very diverse conditions, they share many common features. Most use standards based on the IFOAM Basic Standards (IBS), Codex and/or national regulations adapted to their local socio ecological conditions, small-scale production and processing, and local marketing. Procedures are simple. There is minimal bureaucracy to maintain low costs to farmers or time spent filling-in forms. Most rely on an educational process and social control involving all actors from productive chain focusing on consumer participation to uphold their organic quality system. Transparency is maintained through stimulating active participation within the network." (Fonseca, 2004: 1)

Thus, each PGS is different by design. Each PGS is supposed to self-govern the activities of its members and the linkage with IFOAM or other standards is as a point of reference and recognition, not a hierarchical relationship of control. We explore these differences by looking at two different cases from OECD countries: Chile and Japan. These two examples provide very different contexts for knowing sustainability, but these differences provide us with important insights into standardisation and ways of knowing, which are cross-cutting concerns.

\section{Methodology}

Kom Kelluhayin (the Mapuche Ethical Label), Chile

Founded informally in 1979, Kom Kelluhayin Corporation (CKK) is the first entirely indigenous Mapuche (mapu = earth, che = people - or people of the earth) farmers' association to bring together Mapuche families in the Araucanía region of Southern Chile to preserve the indigenous gastronomic and cultural traditions through the marketing of products produced by Mapuche farmers. In this early period, the focus was on adult education and awareness raising about environmental concerns (particularly the plantation forestry industry) that was being set up in their region and threatened their livelihoods and their environment. In 1999/2000, the first legal structure of CKK was established, which is made of 11 farmers' committees (10 in the municipality of Villarrica and one in the municipality of Panguipulli) that cover the territories of Putue, Calfutúe, Afunalhue, Malloco Lolenco, Hualapulli, Liumalla Sur, Liumalla Centro, Chaura, Quetroco, Challupen y Traitraico. About 250 families participate in the initiative. The original motivation for creating the cooperative during the time of the Pinochet regime was in protest against a lack of State support in the region. In 2003-2005, CKK decided to distinguish themselves in their growing market by creating an ethical label for their products (Sello Etico Mapuche). In 2010, CKK was officially registered as a NGO and farmers' cooperative.

In 2015, 13 semi-structured interviews were conducted with producers, intermediaries and consumers in Villarrica. The initiative sampled in this case consisted of a farmers' group of 25 families. This initiative was selected because of the innovative markets that have been created in 
the Temuco region and because of their mixing of agroecological production with the traditional production methods. Specifically, collaboration was initiated in 2010, with funding from the Agricultural Innovation Fund (FIA) of the Ministry of Agriculture to set up a public-private partnership between six hotels/restaurants, the Farmers' market network (ferias), an artisanal association, and the Agroindustry Institute of the Frontier University of Temuco, and farmers' organisations of the CKK to begin direct sourcing of fresh vegetables and quinoa to the local restaurants. The objective of this project was to contribute to the eco-tourism industry in the Villarrica/Pucón area by promoting Mapuche agro-gastronomy. Following the creation of the CKK label, the group initiated a self-certification process similar to PGS, which was compatible with their socio-political culture which resists external domination - even if only in the form of judging the quality of their food.

\section{Seikatsu Club Consumer Cooperative, Japan}

Seikatsu Club Consumer Cooperative (SCCC) was founded in 1968 in Tokyo, Japan. SCCC originated as a movement in 1965 in which approximately 200 housewives banded together to purchase reasonably priced, safe, and high quality milk for their children. To date, SCCC consists of about 340,000 members across 32 regional branch organisations, and the vast majority of SCCC members remain women who are interested not only in safe but also socially just and environmentally sustainable foods. At the core of SCCC's mission is the belief that consumption is an integral part of life and thus, how to consume and what to consume matter significantly as to what kind of society one will be part of. Consequently, SCCC emphasises to its members that they must be active citizens who recognise the ramifications of their consumption practices. As active citizens, its members work closely with suppliers and view their suppliers as their partners to achieve the organisation's twin goals: (1) production and consumption of sustainable food and (2) development of a sustainable society. In other words, SCCC views that as citizens, SCCC members (consumers) and its suppliers have different roles and responsibilities in achieving the above goals, and only through collaboratively working together can they accomplish these goals. Thus, SCCC's food governance stresses civic engagement and the teikei model. Teikei, in Japanese, stands for partnership. The teikei model emerged in the early 1970s as person-to-person networks between organic farmers and urban consumers (Masugata, 2008). Today, it represents a form of governance based on personal relations and trust.

The effectiveness of SCCC's food governance is well recognised. Notably, in 1989, SCCC received the Right Livelihood Award, which is known as the "Alternative Nobel Prize," for "creating the most successful, sustainable model of production and consumption in the industrial world" (The Right Livelihood Award 2016). viii In 1995, SCCC also received the "We the Peoples 50 Communities'" Award, which was presented to 50 communities around the world whose activities provided concrete expression of the spirit of world peace, by the Friends of the United Nations as part of the 50th Anniversary of the UN Celebrations. While SCCC is not an officially certified PGS by IFOAM, its participatory governance has become a model for many other consumer cooperatives, as well as CSA initiatives globally.

The Japanese PGS case presented in this paper is based on the fieldwork that was conducted in Japan in summer 2014 and 2015. In total of 65 semi-structured interviews were conducted with SCCC leaders, members, officials, suppliers, municipal governmental officials, and university scholars. In addition, participant observation in numerous SCCC activities was undertaken to better understand interactions between different stakeholders who are involved in the SCCC initiative. 
As Wittgenstein once noted, the language one has at their disposal limits a persons' ability to articulate and know their world. Problem framing and concept definition are fundamentally political processes and there are often winners and losers (Cheyns, 2011). Who gets to decide what sustainability means, how they decide this and what forms of knowledge count are all elements that can be influenced by the language and concepts used by different actors (Harding, 1991).

Chile: producers, restaurants, and consumers define and know sustainability In Chile, sustainability is defined mainly by the producers, but it is refined through interactions with restaurants and consumers. CKK defines their agricultural model as 'comprehensive food production units' that are based in family farms. Up until the 1970s, the main model for agroecological production was based a subsistence agriculture model, but was highly influenced by the agricultural modernisation programme of the State. The majority of the traditional Mapuche agricultural practices had been lost through subsequent training programmes in high input, industrial farming methods. As one producer noted, "before, we were destroying our land." With the creation of the CKK, the Mapuche began to reclaim their traditional agricultural practices as part of a general process of re-appropriation of their culture (such as language, social traditions and food). For example, each community has a cultural centre that offers language classes and a local radio station includes daily Mapuche vocabulary and spiritual guidance.

In the 1990s, through a programme with the Temuco Catholic University, the Mapuche in Villarrica began to learn organic and ecological farming methods, which merged well with the four principles of the Mapuche culinary and food tradition. These are:ix

1. Nature and ecosystems are living elements. This animist principle emphasises that there is a material and spiritual element to the interdependent relationships between the Mapuche people and nature. There are natural forces that temper human behaviour and generate reciprocal relationships and respect for all living things. This principle guides agricultural practices that try not to kill nature, but to promote beneficial interactions between plants, animals, insects and humans.

2. Food and Health are intertwined and constitute the quality of life (Küme mongen). This principle guides both cultivation and eating practices, as food is considered to be medicine for the body. Eating well is associated with production practices that all for good health, particularly in the use of diversified plants and seeds that provide different flavours and serve medicinal purposes.

3. Food is tied to life and sociocultural identity. Food is seen as constituting a large part of sociocultural heritage and defines many Mapuche rituals and ceremonies. At the same time, food is part of daily life and the daily habits of slow cooking that bring healthy and tasty food for the satisfaction, well-being and health of those people who consume it. This focus on traditions and flavour translate into equilibrated agricultural practices that protect native varieties (e.g., beans, quinoa and the aruancania chicken) that are used by the local population.

4. Food production and consumption are connected through vital cycles of nature and her respective seasons. Seasonality is fundamental and is respected in both traditional culinary dishes and in cultivation practices. The Mapuche diet has 
dishes that are eaten during the rainy season, during the dry season, during plenty and scarcity. The dishes include food that comes from the garden and the fields (e.g., tomatoes, peas, garlic, onions, potatoes, quinoa) from the diverse livestock (e.g., poultry, lamb, rabbit), and wild collected food from the forests (e.g., fruits, nuts, mushrooms) - but respects their seasonality and farmers do not use technology that changes this natural seasonality.

Thanks to the diverse ecosystems that the Mapuche inhabit, they have been able to cultivate a diversity of produce. Thus, while the families maintain a diverse production (vegetables, beans, fruits, eggs, maize, etc.), the product with the greatest market potential is quinoa. The Mapuche quinoa is unique in being the southernmost variety found South America that can grow in cold, low land climates, and has a strong nutritional profile. With the increased production of quinoa, the CKK members began a transition from subsistence agriculture towards commercial farming. However, they maintain a tacit and personal knowledge of the land that conditions the type of agriculture that they practice. An intermediary explained:

"We are conscious that we make part of the land, we cannot use chemical inputs, I am Mapuche that means son of the Earth, so we cannot destroy it (our universe and cosmology)"

\section{Japan: consumers and producers define sustainability}

SCCC views sustainability as a progressive and aspirational concept that changes and thus needs to be constantly modified according to changing conditions and needs. Hence, for SCCC, sustainability is not something that can be achieved by crossing a threshold. Building on this understanding of sustainability, SCCC emphasises that consumer and producer knowledge is an important component of determining what sustainability entails and how to achieve it. This is because consumers and producers are the ones who are actually living in the community, understand food production and consumption practices, and are often directly affected by their production and consumption practices. For these reasons, SCCC maintains that meaningful understanding of sustainability must emerge from bottom-up and build on the life experiences of everyday people rather than outside experts who have little knowledge of a given community and who will bear little responsibility if something goes wrong.

However, while SCCC embraces lay knowledge and experiences, it does not reject expert knowledge altogether. Indeed, SCCC brings in experts to aid producers and consumers in developing standards. For example, in interviews, one expert who works in the quality assurance division of the SCCC commented: "We can help [SCCC members]. But that is all we should do. The initiative needs to come from them." Thus, whereas third-party governance prioritises expert knowledge and tends to marginalise lay knowledge, SCCC does the reverse. This understanding of self-governance largely corresponds with the principles of co-operatives more generally, which stress the autonomous, self-help characteristics of organisations that are democratically controlled by their members.

To bring SCCC members and its suppliers together to discuss and frame sustainability, SCCC organises a wide array of events, get-togethers, and study sessions. These include cooking and dining session in which a supplier group comes and visit SCCC members, and farm assistance trips where a group of SCCC members visits a supplier farm and works on the farm. SCCC sees the teikei model (supplier-consumer partnership), mutual understanding and commitment, and 
trust relationship between its members and suppliers as a building component of its sustainable food system.

Measuring

The core metrics used in both cases are standards for organic production. While in both cases, the standards are based on national legal regulations, neither group uses the national organic labels on their products. Instead, they have spent considerable time and energy adapting these national standards and metrics specifically for their context-specific production and consumption systems.

\section{Chile: Producer-led metrics}

CKK's standards are based on an ethics that guides production (the Mapuche cosmology), as was explained above. Given the history of colonial control, the CKK leadership explained that it was important for them to reorganise what they had learned about organic practices within their understanding of the Mapuche cosmology and the agricultural practices of their grandfathers. This meant a shift from standard criteria that are measured via checklists and scientific tests, to a set of inalienable principles that were to guide the individual implementation of organic practices.

Sustainable agriculture is therefore measured according to the extent to which it is: 1) Produced within the limits of the Mapuche territory, so to ensure that any products are easily identified as Mapuche products; 2) Produced by small-scale family farmers, which ensures that they can maintain their culture of family farming; 3) Produced using agroecological practices. These are defined in relation to the national organic (ecologic) law, but there are no scientific tests (e.g., maximum residue limits) required for most products, except for Quinoa because of the classification of the Mapuche Quinoa as a unique, native variety; 4) Produced from native/indigenous seeds and livestock breeds. The main crops that this applies to are: quinoa, potatoes, beans, chickens, and tree species for the wild, collected crops; and finally, 5) Traded on fair trade principles. This means that not only must the producers be conscientious producers, but consumers must also be conscientious consumers. The original mission of the CKK was to produce food for the farmers' own consumption but also for the wider Mapuche, community. However, with the increasing demand for agroecological products by tourists who are visiting the ecotourism sites in the area, the consumer base is expanding (FAO, 2017).

These standards were developed by the Executive Committee of Mapuche Farmers who meet twice per year to discuss, review and revise the standards. Additional expertise for the writing of these standards come from the Seed Custodians (nodal famers who save native seeds and breed native livestock) and scientists from the Catholic University of Temuco, in particular for the quinoa and agroecological practices (Aleman et al., 2010). Indeed, the standards were not formalised until the research on the Mapuche Quinoa and Hens (a breed that lays blue eggs) had been completed in 2009 by group of local and international researchers who worked with the CKK to study the nutritional properties of the Mapuche's native breeds (Martínez et al., 2010; Bazile, 2015; Navarro et al., 2009). It is for this reason, that the only scientific tests that are required by the standard are those that can identify the low-land Quinoa (based on a micronutrient profile). This and other indigenous varieties are particularly appreciated by consumers:

"the quinoa variety (manteca) is good because is easier to cook and soft, it is not hard. The size of the beans (poroto); the visual measure, is how we can tell that the variety is the right one and that it will have the taste and nutrients that we want." 
Japan: Consumer- and producer-led metrics

SCCC formalised its sustainability governance mechanism in 1997. From the perspective of SCCC, one of the primary purposes of its sustainability governance mechanism is to offer a site for SCCC members and its suppliers to work collaboratively towards the development and maintenance of a sustainable agrifood system and more generally, a sustainable society. In developing and implementing its quality assurance mechanism, what SCCC emphasises is the autonomy of its members and suppliers-i.e., self-regulation and self-management. Thus, in SCCC's quality assurance practices, SCCC members and suppliers play a central role in determining what sustainability entails and how to achieve it, and SCCC officials facilitate this collaborative effort. In interviews, the SCCC officials commented that while the SCCC standard in its initial form in 1997 was not that sophisticated, it has come a long way since then and is now quite comprehensive.

The SCCC standard covers six areas: agriculture; fisheries; livestock; processed food; household goods; and containers and packaging. Under each area, there are numerous criteria. For example, the agriculture standard contains 25 primary criteria that include such things as information disclosure, agriculture facilities and materials, soil formation, fertiliser, pesticides, and traceability. Each criterion is divided into two tiers: required or recommended. The required metrics are a set of minimum metrics that all the suppliers are expected to abide by. The recommended metrics serve as a benchmark to guide supplier practices in shifting towards more sustainable practices. SCCC members argue that a critical role of the recommended metrics is to provide a site for being reflective about the food production. Specifically, they function as the basis for maintaining SCCC's aspirational trajectory towards continuous improvement. Many of the recommended metrics are qualitative in nature and include social and economic sustainability components, such as school children (future generational) education on food issues and Japanese culture, and securing and training young farmers.

Organisationally, the SCCC standard is managed by the self-management committee, which is a joint committee consisting of 30 members that include SCCC members, suppliers, and SCCC staff. Under the self-management committee, there are 10 specialised subcommittees: agriculture, fisheries, livestock, processed foods, household goods, package and containers, lab and microorganisms, green systems, carbon reduction, and risk management. Each of these subcommittees also contains SCCC members, suppliers, and SCCC staff. The role of subcommittees is to stay up-to-date on production practices, new knowledge, and problems and concerns facing SCCC members and suppliers, and to recommend potential revisions to the SCCC standard. The self-management committee uses the information compiled by the subcommittees to annually review and revise the standard as necessary. Hence, the SCCC standard is not fixed and is rather designed to be adaptable to changing conditions and environment.

\section{Assessing}

Conformity assessment - controlling for compliance with a standard - is a fundamental part of how one knows if practices (and reality) align with a certain group's vision for sustainability. Recent work begins to unpack how different audit techniques might have different effects on production practices (Hatanaka, 2015; Loconto, 2017), this suggests that who conducts audits, why and how they are conducted also contributes to what is known about sustainability. 
Chile: communities of producer-auditors

The audits in CKK are not called audits, they are called social control (control social) because it is a peer review that is based on farmers visiting their neighbours' farms and comparing agroecological practices. According to interviewees, the CKK Review Committee made up of farmers because: 1) they are knowledgeable about natural or agroecological production; 2) they are seed custodians (i.e., nodal farmers); and 3) they hold knowledge about the Mapuche cosmology/culture. In recent years, the original group has expanded to include consumers into these committees. Because of the strong tradition of linking food preparation directly with the growing techniques - and because the majority of them are members of farm families - the 'Cocineras Mapuche' (Mapuche Cooks) were the first 'consumers' to participate in the review committees and remain active members in controlling the production practices.

CKK conducts its social control regularly, but there is an official yearly visit that releases the certificate and use of the label that lasts for one year. The visit consists of a visit to the fields and farm facilities and discussion about the farm documents. Particular attention is paid to agroecological practices and the 'cleanliness' of the products, for example, a consumer member of the review committee noted that "we often control that all is clean, the water and everything."

A restaurant member explained that they make: "the same quality control that is made for other conventional products. But the difference is that the agro-industry works a lot on calibrating the metrics, but agroecology is not so demanding."

Nonetheless, the intermediate controls that are conducted (ranging from monthly to a maximum of every season) ensure that the system is rigorous. A farmer member of the review committee explained that:

"in our certification system, there are those who succeed and those who don't, but it is a learning process. We pay more attention to the individual needs and capacities."

When there are problems with the farmers' production, for example a pest attack or a fungus, the review committee provides advice on how to deal with it in an ecological manner so to rebalance the forces of nature according to the four poles of the Mapuche cosmology. During the visits there is also discussion and sharing of farmer and consumer knowledge; such as, when to pick for specific crops that are needed in some traditional dishes or the right time of day to check for specific pests.

Currently the CKK finds themselves in a transition period, they are now certifying products (with quinoa as the main product), but they are transitioning into the certification of producers instead (because of the range of products that are now sold). This is also indicative of the changing vision of the role and value of farmer's knowledge. As the standard itself was created around a single product (Quinoa) based on their collaboration with the local and international scientists, the product-based assessment followed their interest in this one unique variety. However, for CKK and its farmers, the family farm and the entirety of its production is more important. There is also a history of exploitation behind this movement whereby the CKK community felt exploited by their university partners who had collaborated with them in an extractive way - collecting their knowledge and keeping all of the research funds for themselves. Therefore, they have shifted from an external, individualist method of assessment towards an internal, communitarian method that is more suited to their ethics and priorities. As one farmer declared, 
"we will no longer be subjected to controls by outsiders. We are the ones who know how to farm ecologically and we are the ones who know how to judge this."

\section{Japan: Hired experts' inspection and consumer groups' audits}

Two sets of audits are conducted as part of SCCC's sustainability food governance: 1) SCCC staff inspection and 2) "audit by many" (ABM) by a group of SCCC members. SCCC views these both of these two audit processes as complimentary and indispensable components of its sustainability assessment mechanism. SCCC staff inspection is similar to a third-party audit. Before a supplier can provide a new product to SCCC, staff from the SCCC Quality Control division conduct an onsite inspection and check the supplier's compliance with the required SCCC standards.

Additionally, SCCC officials also conduct random spot tests on products once they arrive at SCCC shipping. SCCC owns its own laboratory and specialised laboratory staff conduct a variety of lab tests to ensure product quality.

The second component of SCCC's conformity assessment mechanism is what sets it apart from other sustainability governance initiatives. While SCCC acknowledges the importance of its staff inspection, it claims that $\mathrm{ABM}$ is the most important component of its conformity assessment mechanism. As one SCCC member noted, “ABM represents who we are." In brief, ABM is an audit that is conducted by a group of SCCC members at a supplier's facility. Any SCCC members can participate in an $\mathrm{ABM}$ and freely choose which product and supplier to audit. In doing an ABM, the expense is covered by SCCC. Typically, the audit team consists of five to 10 members and is led by a member that has participated in an ABM previously. Prior to the actual audit, the team will receive the "tool of audit" - kansa no dougu - which consists of supplier registration documents, the product proposal document, and any previous ABM reports on the product. Using the tool of audit package, the team members organise a study session to investigate a wide array of issues concerning the particular product, and to choose a theme or topic to focus on. On the audit day, a significant amount of time is allocated for a discussion between the audit team (i.e., SCCC members) and the supplier. After the audit, the audit team prepares an evaluation report, which they submit to both the supplier and the SCCC leadership. The supplier has a right to review the audit report and provide comment. The audit results are then uploaded on the SCCC website and made available to all SCCC members.

The goal of ABM is two-fold: 1) to help foster mutual understanding between SCCC members and suppliers regarding their needs, interests, and limitations, and 2) to build relationships of trust between SCCC members and suppliers. SCCC strongly believes that having a one-shot audit that results in a pass or a fail outcome is insufficient to ensure product quality and long-term sustainability. Rather, from the perspective of SCCC, effective conformity assessment requires relationships and trust. In describing the importance of the ABM process, one SCCC staff commented:

"ABM is a mechanism for both producers and consumers to progress. Consumers learn about the production site, suppliers, and their aspirations and challenges. Producers learn what consumers want, what consumers think and how they think. It's a site for both of them to understand each other, and a site of discussion... Through direct dialogues, a product can be improved towards further sustainability."

Put differently, the ABM process allows producers and consumers to identify current possibilities, areas of improvement, and goals to aspire to. 


\section{Discussion}

These two cases provide new empirical data that enable us to reflect upon how PGS provide different ways of defining, measuring, and assessing sustainability. There are significant differences in the activities of the two groups: in Chile, the focus is on an indigenous producer culture where the majority of consumers are also producers, while in Japan, the focus is on a consumer culture where the majority (if not all) consumers are not producers. They are both dealing with very short supply chains, but the types of products and actors involved in the initiatives, their understanding of sustainability, and the socio-cultural, economic and environmental conditions of the producers and consumers in these two cases are quite different. These foundational features are interesting to examine in contrast to each other because despite the above noted clear differences, we find a number of similarities when we look at the politics of knowledge.

With regards to the type of knowledge that is privileged in the definition of what sustainable production practices are, we see two different approaches in action. In the case of the CKK in Chile, the PGS mechanism privileges farmers' knowledge that is based on indigenous and learned agroecological knowledge. The SCCC in Japan privileges consumer knowledge of their needs and learned agroecological knowledge. In both cases, we see a rejection of the principle of independent knowledge as one of the defining features of expert knowledge. Instead, we see a preference for the knowledge of "interested" and "embedded" actors. These PGS initiatives view consumers and producers as actors who are able to know sustainability, as one producer in Chile noted, actors "that consume and produce the food are most committed to the community and environment and therefore, are best equipped to design a sustainable food system."

How then, do these interested actors measure the sustainability of their practices? In both cases we see a focus on flexible principles that guide their activities, which illustrates the point made by Raban (2010: 177) that "clear rules are bound to produce less certainty and predictability than vague standards in many areas of the law." Nonetheless, this flexibility of interpretation does not mean a lack of quantifiable measures, particularly in Japan. Rather, it refers to the recognition of diversity that is fundamental to agroecological production. Moreover, the use of adherence to principles over strict, check-listed measures also points to an alternative ethics of reciprocal responsibility among members of the collective. In both cases, we see a heightened preoccupation for fair trading between consumers and producers, achieved through direct contact and communication, that ensures the sustainability of their systems. This latter type of sustainability is effectively known through the social and economic practices of members. In the long term, the durability of the social and economic relations is what ensures the environmental sustainability of these initiatives as these relations ensure that members continue to use organic production practices. These practices in turn ensure the environmental sustainability of the initiatives.

The assessment activities follow the same pattern as the defining and measuring practices. We see an increased reliance upon farmer (Chile) and consumer (Japan) knowledge, with scientific knowledge providing support for the assessments rather than driving them. We also see a rejection of 'third-parties' in both cases, which is linked to the prioritisation of 'interested' knowledge. We traced this clearly through the shift in language from 'audit' to 'review' or 'audit by many' in both of the cases. What is interesting to note here is that despite a rejection of scientific knowledge, to different extents in the two cases, we can see the actors in both cases bringing their systems back towards scientific language with the term 'peer review.' The 
difference here is that this language signifies a significant shift in thinking - no longer is science conducted on farmers and consumers - but they are the scientists who constitute the peer community that has the knowledge and competence to maintain the norms of its community without the need for external oversight.

\section{Conclusions}

In this article, we have demonstrated how paying attention to 'knowledge politics' can improve our understanding of the implementation of sustainability governance. Specifically, we have demonstrated, through two case studies, how knowledge politics within PGS directly oppose some of the long-held assumptions of the dominant third-party certification models. In concluding, we highlight three findings from our two case studies that have implications for sustainability governance more generally.

First, while sustainability is defined in different terms in these two different cases, it is still comprehensible as a holistic concept that needs to be based on direct reciprocal responsibility and accountability between producers and consumers. In terms of the definition of sustainability, we see two processes that are driven by the core membership of the initiatives: producers in Chile and consumers in Japan. However, an important value that has emerged in both cases is the notion of shared or reciprocal responsibility of producers to consumers and vice versa. This observation posits a question that remains to be answered by more comprehensive studies of PGS: is this model of reciprocal responsibility something that can withstand long geographical, socio-economic and cultural distances or does it necessarily require locally rooted initiatives? Our focus on the politics of knowledge suggest that interpersonal and community rooting is a necessary feature of a PGS's ability to function as a credible control mechanism. However, this does not suggest that PGS cannot be adapted by autonomous initiatives in many locales around the world as shown by recent studies (FAO 2016, IFOAM 2008). Indeed, what our results do demonstrate is that the principles of PGS can provide local guarantees in more than one place depending on how the groups adapt and integrate them to their local contexts.

Second, we see the privileging of different types of 'expert' knowledge, which result in a range of hybrid actors: Farmer-experts - who are allowed/encouraged to experiment to find solutions to their problems; Farmer-auditors - who are required to conduct 'peer-reviews'; Producerconsumers (or 'prosumers') (Toffler, 1980) - who are very knowledgeable about what they are eating and why; Consumer-citizens - who are creating democratic structures within civic and private relations. This apparent actor hybridity challenges some of our long-held visions about the separation of roles in agri-food chains and what constitutes a conflict of interest in their certification (cf. Lytton, 2014). We see actions such as giving advice and controls by members of the same group transformed from conflicts to compromises and mutual interdependence. In these two specific cases, the idea that there is a conflict of interest is refuted, particularly since we see the emergence of hybrid actors who are embodying some of the more well-known conflicts of interest such as the combination of evaluator and farmer advisor.

Third, metrics and assessments are difficult to disentangle from each other and from the definition of sustainability. The Japanese PGS that is driven by consumers contains much more of a reliance upon scientific measures than the Chilean PGS. The consumer perspective is still too far removed from the farm to 'trust' famers' metrics and knowledge as the only way to assess sustainable practices. The Chilean PGS has developed scientific metrics only for its quinoa 
because it is the core commercial product. The producer reliance on the renewal of a Mapuche territorially-grounded identity has strong local applicability and can be maintained with the linkage to the growth of eco-tourism in the area - but there is little trust in consumer knowledge if those consumers are not part of the Mapuche community. These metrics illustrate a resurgence of producer and consumer re-appropriation of the definition of sustainability - away from 'independent' actors who embody 'impersonal' and 'unbiased' knowledge. Thus, while producers and consumers still have trouble trusting each other, they find producer or consumer led metrics preferable to the third-party model.

These insights demonstrate Nikolas Rose's (1991: 673) argument that democratic power is "calculated power, calculating power and require[s] citizens who calculate about power." Put within the context of food systems, for a system to become more democratic, the power to calculate must also become distributed among the citizens. The cases that we described here are examples of democratising food systems because they are enabling producers and consumers to exercise calculating power through PGS-oriented systems that have shifted knowledge about sustainability away from centralised, independent calculators towards more distributed calculating actors. Future studies of sustainable food systems should pay more attention to these politics of knowledge so to better assess the potentials for transformative change towards more democratic forms of governance.

i http://www.fao.org/about/meetings/afns/en/, accessed 30/11/2014

ii http://www.oxfam.org/en/grow/pressroom/reactions/oxfam-response-un-committee-world-food-securityendorsement-principles, accessed 30/11/2014

iii http://www.fao.org/about/meetings/icn2/en/, accessed 30/11/2014

iv http://www.fao.org/about/what-we-do/so2/en/, accessed 25/09/2016

$\mathrm{v}$ http://www.fao.org/about/who-we-are/director-gen/faodg-statements/detail/en/c/247970/accessed 30/11/2014

${ }^{v i}$ http://www.ifoam.bio/en/pgs-maps, accessed 24/07/2017

vii Official IFOAM PGS Definition, accessed 25 September 2016, http://www.ifoam.org/en/valuechain/participatory-guarantee-systems-pgs

viii http://www.rightlivelihood.org/seikatsu.html

ix These categories are explained in Peralta Celis C. (2016) Patrimonio culinario y alimentario mapuche: acercamientos y contribuciones para su puesta en valor. This book was given to the author by an interviewee and further explained during an interview with a CCK leader.

\section{References}

Agrawal A. (2014) Indigenous and Scientific Knowledge: Some Critical Comments.

Aleman J, Thomet M, Bazile D, et al. (2010) Central Role of Nodal Farmers in Seed Exchanges for Biodiversity Dynamics Example of «Curadoras » for the Quinoa Conservation in Mapuche Communities in South Chile. ISDA 2010. Montpellier, France: Cirad-InraSupAgro, $14 \mathrm{p}$.

Amin A and Roberts J. (2008) Knowing in action: Beyond communities of practice. Research Policy 37: 353-369.

Apple MW. (2001) Standards, subject matter, and a romantic past. Educational Policy 15: 323333.

Aubert P-M, Herman D and Laurans Y. (2016) Mesurer la forêt pour lutter contre la déforestation ?. Une lecture pragmatique de l'émergence du « High Carbon Stocks Approach ». Terrains \& travaux 28: 85-107. 
Baert P and Rubio FD. (2012) The politics of knowledge, London ; New York: Routledge.

Bain C, Ransom E and Worosz M. (2010) Constructing Credibility: Using Technoscience to Legitimate Strategies in Agrifood Governance. Journal of Rural Social Science 25: 160192.

Bazile D. (2015) Le quinoa, les enjeux d'une conquête: Quae.

Bingen J. (2002) Shaping our agro-food system: Whose standards count? Guest editor observations. Agriculture and Human Values 19: 279-281.

Boullier H. (2016) Évaluer des dossiers « vides ». L'expertise REACH face aux asymétries d'information. Terrains \& travaux 28: 41-61.

Bowker GC and Star SL. (1999) Sorting things out: classification and its consequences, Cambridge, MA: MIT Press.

Busch L. (2007) Performing the economy, performing science: from neoclassical to supply chain models in the agrifood sector. Economy and Society 36: 437-466.

Busch L. (2011a) The private governance of food: equitable exchange or bizarre bazaar? Agriculture and Human Values 28: 345-352.

Busch L. (2011b) Standards: Recipes for Reality, Cambridge, MA: MIT Press.

Cheyns E. (2011) Multi-stakeholder Initiatives for Sustainable Agriculture: The Limits of the 'Inclusiveness' Paradigm. In: Ponte S, Gibbon P and Vestergaard J (eds) Governing Through Standards Houndmills, Basingstoke, Hampshire; New York: Palgrave Macmillan, 210-235.

Cochran-Smith M and Lytle S. (2006) Troubling Images of Teaching in No Child Left Behind.

Harvard Educational Review 76: 668-697.

Collins H. (2014) Rejecting knowledge claims inside and outside science. Social Studies of Science 44: 722-735.

Dagiral É, Jouzel J-N, Mias A, et al. (2016) Mesurer pour prévenir ?. Entre mise en nombre et mise en ordre. Terrains \& travaux 28: 5-20.

Denny RCH, Worosz MR and Wilson NLW. (2016) The Importance of Governance Levels in Alternative Food Networks: The Case of Red Meat Inspection Rules. Rural Sociology: n/an/a.

FAO (2016) Innovative markets for sustainable agriculture: How innovations in market institutions encourage sustainable agriculture in developing countries. Loconto A, Poisot AS and Santacoloma P (Eds.) Rome: Food and Agriculture Organization of the United Nations.

FAO. (2017) Constructing markets for agroecology. An analysis of diverse options for marketing products from agroecology. Loconto A, Jimenez A and Vandecandelaere E (eds). Rome: Food and Agriculture Organization of the United Nations.

Fonseca, M.F. (2004) Alternative certification and a network conformity assessment approach. Bonn: International Federation of Organic Agriculture Movements (IFOAM).

Fouilleux E and Loconto A. (2016) Voluntary standards, certification, and accreditation in the global organic agriculture field: a tripartite model of techno-politics. Agriculture and Human Values: 1-14.

Fransen L. (2015) The politics of meta-governance in transnational private sustainability governance. Policy Sciences: 1-25.

Freidberg S. (2013) Calculating sustainability in supply chain capitalism. Economy and Society 42: 571-596.

Freidberg, S. (2014) Footprint technopolitics. Geoforum, 55: 178-189.

Harding SG. (1991) Whose science? Whose knowledge? Thinking from women's lives, Ithaca, NY: Cornell University Press.

Hatanaka M. (2010a) Assessing Rule-Based Governance Mechanisms in an Era of Scientism. Journal of Rural Social Science 25: 141-159.

Hatanaka M. (2010b) Governing sustainability: examining audits and compliance in a thirdparty-certified organic shrimp farming project in rural Indonesia. Local Environment 15: 233-244. 
Hatanaka M. (2014) McSustainability and McJustice: Certification, Alternative Food and Agriculture, and Social Change. Sustainability 6: 8092-8112.

Hatanaka M. (2015) Organic Certification and the Rationalization of Alternative Food and Agriculture: Sustainable Shrimp Farming in Indonesia. In: Freyer B and Bingen J (eds) ReThinking Organic Food and Farming in a Changing World. Dordrecht: Springer Netherlands, 45-60.

IFOAM. (2008) Participatory Guarantee Systems: Case studies from BRAZIL, INDIA, NEW ZEALAND, USA and FRANCE. Bonn, Germany: International Forum for Organic Agriculture Movements (IFOAM).

Jasanoff S and Kim S-H. (2009) Containing the Atom: Sociotechnical Imaginaries and Nuclear Power in the United States and South Korea. Minerva 47: 119-146.

Lascoumes P and Le Gales P. (2007) Introduction: Understanding Public Policy through Its Instruments-From the Nature of Instruments to the Sociology of Public Policy Instrumentation. Governance 20: 1-21.

Leach M and Scoones I. (2013a) Carbon forestry in West Africa: The politics of models, measures and verification processes. Global Environmental Change 23: 957-967.

Leach M and Scoones I. (2013b) The social and political lives of zoonotic disease models: Narratives, science and policy. Social Science \& Medicine 88: 10-17.

Levin K, Cashore B, Bernstein S, et al. (2012) Overcoming the tragedy of super wicked problems: constraining our future selves to ameliorate global climate change. Policy Sciences 45: 123-152.

Lide DR. (2001) A Century of Excellence in Measurements, Standards, and Technology: A Chronicle of Selected NBS/NIST Publications, 1901-2000. NIST Special Publication 958. Washington, DC: National Institute of Standards and Technology.

Loconto A. (2010) Sustainably Performed: Reconciling Global Value Chain Governance and Performativity. Journal of Rural Social Science 25: 193-225.

Loconto A. (2014) Sustaining an Enterprise, Enacting SustainaibliTea. Science, Technology \& Human Values 39: 819-843.

Loconto A. (2015) Can Certified-Tea Value Chains Deliver Gender Equality in Tanzania? Feminist Economics 21: 191-215.

Loconto A. (2017) Models of Assurance: Diversity and Standardization of Modes of Intermediation. The Annals of the American Academy of Political and Social Science 670: $1-21$.

Loconto A and Barbier M. (2014) Transitioning Sustainability: Performing 'governing by standards'. In: Borrás S and Edler J (eds) The Governance of Socio-Technical Systems: Theorising and Explaining Change. Cheltenham, UK: Edward Edgar, 70-95.

Loconto A and Busch L. (2010) Standards, techno-economic networks, and playing fields: Performing the global market economy. Review of International Political Economy 17: $507-536$.

Loconto A and Vicovaro M. (2016) Why and how market institutions create incentives for adopting sustainable agricultural practices. In: Loconto A, Poisot AS and Santacoloma P (eds) Innovative markets for sustainable agriculture. Exploring how innovations in market institutions encourage sustainable agriculture in developing countries. Rome: Food and Agriculture Organization of the United Nations., 327-364.

Lytton TD. (2014) Competitive Third-Party Regulation: How Private Certification Can Overcome Constraints That Frustrate Government Regulation. Theoretical Inquiries in Law. 539.

MacKenzie D. (2007) Is Economics Performative? Option Theory and the Construction of Derivative Markets. In: MacKenzie D, Muniesa F and Siu L (eds) Do Economists Make Markets? On the Performativity of Economics. Princeton, NJ and Oxford: Princeton University Press, 54-86.

MacKenzie DA, Muniesa F and Siu L. (2007) Do economists make markets? : on the performativity of economics, Princeton, NJ: Princeton University Press. 
Martínez EA, Bazile D, Thomet M, et al. (2010) NEO-LIBERALISM IN CHILE AND ITS IMPACTS ON AGRICULTURE AND BIODIVERSITY CONSERVATION OF QUINOA: A LESSON FOR STRENGTHENING AND DEVELOPING NEW PARTNERSHIPS. ISDA 2010. Montpellier, France: Cirad-Inra-SupAgro, $11 \mathrm{p}$.

Marx A. (2012) Private standards and global governance : economic, legal and political perspectives, Cheltenham, UK ; Northampton, MA: Edward Elgar.

Masugata, Toshiko. (2008) Yuukinougyou undou to teikei no network (Network between organic agriculture movement and teikei), Tokyo, Japan: Shinyosha.

McDermott CL. (2012) Trust, legitimacy and power in forest certification: A case study of the FSC in British Columbia. Geoforum 43: 634-644.

Meyer M. (2010) Caring for Weak Ties - the Natural History Museum as a Place of Encounter Between Amateur and Professional Science. Sociological Research Online 15: 9.

Milder JC, Arbuthnot M, Blackman A, et al. (2015) An agenda for assessing and improving conservation impacts of sustainability standards in tropical agriculture. Conservation Biology 29: 309-320.

Mundler, P, Bellon, S. (2011). Les Systèmes participatifs de garantie : une alternative à la certification par organismes tiers ?. Pour, 212,(5): 57-65. doi:10.3917/pour.212.0057.

Muniesa F, Millo Y and Callon M. (2007) An introduction to market devices. The Sociological Review 55: 1-12.

Navarro R, Marcela Aguilera, Félix Bórquez, et al. (2009) Resultados y Lecciones en Selección y Manejo de la Gallina Mapuche Productora de Huevos Azules. Proyecto de Innovación en Regiones del Biobío y de La Araucanía. Valorización a diciembre de 2009. SERIE EXPERIENCIAS DE INNOVACIÓN PARA EL EMPRENDIMIENTO AGRARIO. Santiago de Chile: Fundación para la Innovación Agraria, Ministerio de Agricultura.

Ouma S. (2015) Assembling export markets : the making and unmaking of global food connections in West Africa, Chichester, West Sussex, UK ; Malden, MA: John Wiley \& Sons Inc.

Peralta Celis C. (2016) Patrimonio culinario y alimentario mapuche : acercamientos y contribuciones para su puesta en valor.

Poméon, T, Fouilleux E, Lemeilleur S, and A Loconto (2017) L'agriculture biologique en france, entre projet critique et conventionnalisation. Pp. 181-198 in G. Allaire and B. Daviron eds., Transformations et transitions dans l'agriculture et l'agro-alimentaire. Paris: Editions Quae.

Ponte S and Cheyns E. (2013) Voluntary standards, expert knowledge and the governance of sustainability networks. Global Networks 13: 459-477.

Porter TM. (1995) Trust in Numbers: The Pursuit of Objectivity in Science and Public Life, Princeton: Princeton University Press.

Power M. (1997) The Audit Society: Rituals of Verification, Oxford, UK: Oxford University Press. Raban 0. (2010) The Fallacy of Legal Certainty: Why Vague Legal Standards May Be Better for Capitalism and Liberalism. Boston University Public Interest Law Journal 19: 175-191.

Radomsky G, Niederle P and S Schneider (2014) "Participatory systems of certification and alternative marketing networks." Pp. 79-98 in, Rural development and the construction of new markets. New York: Routledge.

Ransom E, Hatanaka M, Konefal J, et al. (2017) Science and Standards. In: Tyfield D, Lave R, Randalls S, et al. (eds) The Routledge Handbook of the Political Economy of Science. New York: Routledge, 329-340.

Reinecke J. (2010) Beyond a subjective theory of value and towards a 'fair price': an organizational perspective on Fairtrade minimum price setting. Organization 17: 563581.

Rose N. (1991) Governing by numbers: Figuring out democracy. Accounting, Organizations and Society 16: 673-692.

Silva-Castañeda L. (2012) A forest of evidence: third-party certification and multiple forms of proof - a case study of oil palm plantations in Indonesia. Agriculture and Human Values 29: 361-370. 
Star SL. (1999) The Ethnography of Infrastructure. American Behavioral Scientist 43: 377-391. Toffler A. (1980) The third wave, New York: Morrow.

Wynne B. (1996) May the Sheep Safely Graze? A Reflexive View of the Expert-Lay Knowlege Divide. In: Lash S, Szerszynski B and Wynne B (eds) Risk, Environment and Modernity: Towards a New Ecology. London: Sage Publications.
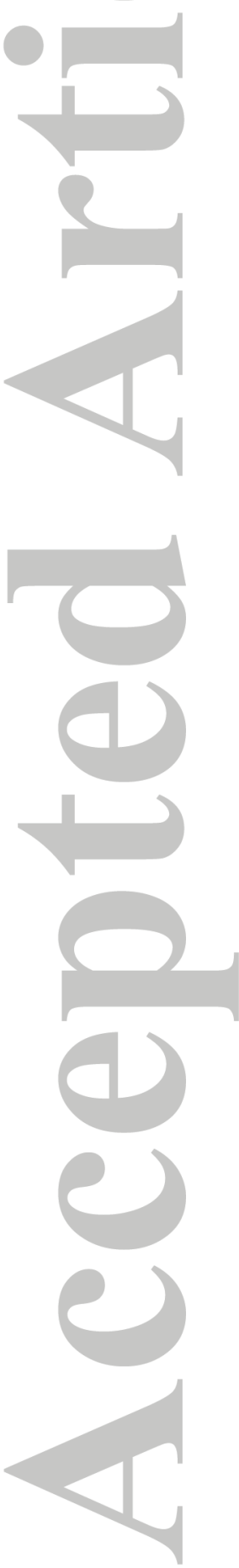